\title{
Designation of a Neotype for the Dwarf Sea Hare Aplysia concava G. B. Sowerby I, 1833, and a Review of the Status of Aplysia norfolkensis G. B. Sowerby II, 1869 (Mollusca: Heterobranchia)
}

\author{
Matt J. Nimbs \\ Southern Cross University, National Marine Science Centre, \\ Bay Drive, Coffs Harbour NSW 2450, Australia
}

\begin{abstract}
A recent revision of the globally distributed dwarf sea hare Aplysia parvula sensu lato split that species into 10 separate taxa. As Australian specimens were not included in this revision, further study using material from the south west Pacific was warranted. At least one described species, Aplysia concava, was found to occur in southeastern Australia, New Zealand and New Caledonia. A redescription of this species was published by Nimbs \& Wilson (2021) even though the holotype was deemed lost - the difficulty, in 2020-2021, to access important and relevant museum specimens, prevented the designation of an appropriate neotype at that time. The present study is an annexure to the published redescription for the purpose of designating a neotype for Aplysia concava and provides a discussion on the taxonomic status of another dwarf sea hare species, Aplysia norfolkensis, which is herein regarded as a junior synonym of $A$. concava.
\end{abstract}

\section{Introduction}

The sea hare genus Aplysia Linnaeus, 1767 is the most speciose genus in the marine mollusc family Aplysiidae Lamarck, 1809 (Nimbs et al., 2017a,b). The dwarf sea hare, Aplysia parvula Mörch, 1863 sensu lato, was once thought to be a globally distributed taxon, but a recent study by Golestani et al. (2019) divided it into 10 species, many of which are cryptic. In that study, Australian animals were not examined and, consequently, Australian Aplysia parvula s. $l$. warranted further study. Given the presence of cryptic species complexes among Indo-Pacific A. parvula s. l., molecular data from Australian specimens were analysed in an attempt to identify any unknown or previously unrecognized species (Nimbs \& Wilson, 2021).
Among Australian specimens of dwarf sea hares, only Aplysia concava G. B. Sowerby I, 1833, was found (Nimbs \& Wilson, 2021). Golestani et al. (2019) reported the $A$. concava holotype lost and, as the original description was based solely on a shell, they could not differentiate it from any of the other species examined in their study. Consequently, they considered Aplysia concava to be a taxon inquirendum (Golestani et al., 2019).

Recently collected specimens from the Australian east coast and some museum-material conformed to the original description of A. concava by G. B. Sowerby I and, with additional molecular data, a redescription was published by Nimbs \& Wilson (2021). During their study in 2020 additional museum specimens of Australian Aplysia parvula 


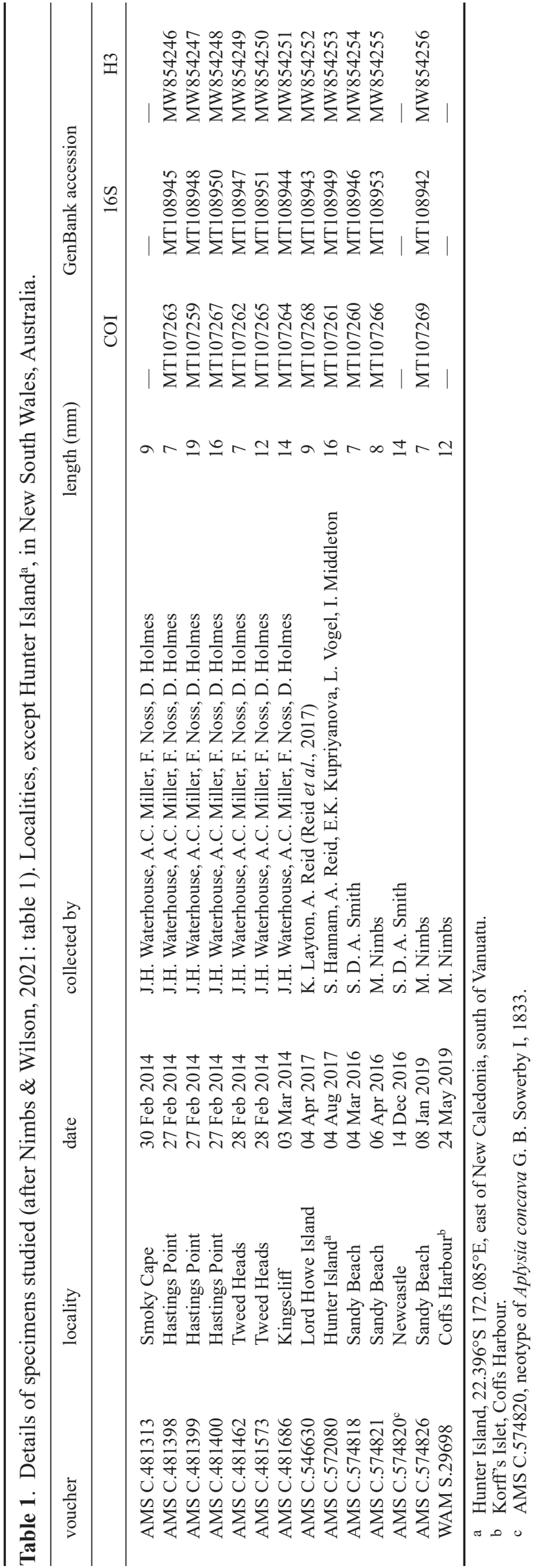

s. l. could not be accessed for loan due to museum closures. As a result, a neotype for Aplysia concava was not then designated. Furthermore, examination of museum material of another potential Australian A. parvula s. l. species, Aplysia norfolkensis G. B. Sowerby I, 1869 (synonymized with $A$. parvula by Eales (1960) was needed to clarify its taxonomic status. Aplysia norfolkensis was not examined by Golestani et al. (2019).

The purpose of the present study is to further affirm that the $A$. concava holotype is indeed lost and to designate an appropriate neotype to replace it. Once the available names are connected to available specimens we then explore the taxonomic status of A. norfolkensis.

\section{Methods}

Thirteen specimens from eastern Australian and one from Hunter Island (east of New Caledonia) were examined. These consisted of nine specimens sourced from the Australian Museum, Sydney (AMS), and four whole specimens collected from various localities in northern New South Wales (NSW) (Table 1 after Nimbs \& Wilson, 2021: table 1). Material was examined and photographed using an Olympus S2×7 binocular microscope with an Olympus DP26 overhead-mounted digital camera. Living specimens were photographed using an Olympus TG6 camera.

\section{Systematics}

\section{Family Aplysiidae Lamarck, 1809}

Genus Aplysia Linnaeus, 1767

\section{Aplysia concava G. B. Sowerby I, 1833}

Fig. 1

Sowerby I (1833) described Aplysia concava based on a shell from an unknown location. The type specimen could not be found at the UK Natural History Museum and is likely lost (A. Salvador pers. comm., cited in Golestani et al., 2019; Nimbs \& Wilson, 2021).

In accordance with Article 75.3 of The Code (ICZN 1999), specimen AMS C. 574820 collected from Newcastle, NSW, on 14 December 2016 by Stephen D. A. Smith is here designated as neotype for Aplysia concava G. B. Sowerby I, 1833 for the purpose of clarifying the taxonomic status of the species (Fig. 1). Characters that define the neotype and differentiate it from other taxa in the Aplysia parvula s. l. species complex are listed in Nimbs \& Wilson (2021).

Although the type locality for Aplysia concava was not specified by Sowerby I, it was listed as "Australia" by Sowerby II in 1869. Given the broad geographic scope associated with this putative original type locality, a specimen collected from Newcastle, NSW on the central east Australian coast was selected as a reasonable neotype. The neotype has been lodged with the Australian Museum, Sydney, Australia (AMS C.574820). 


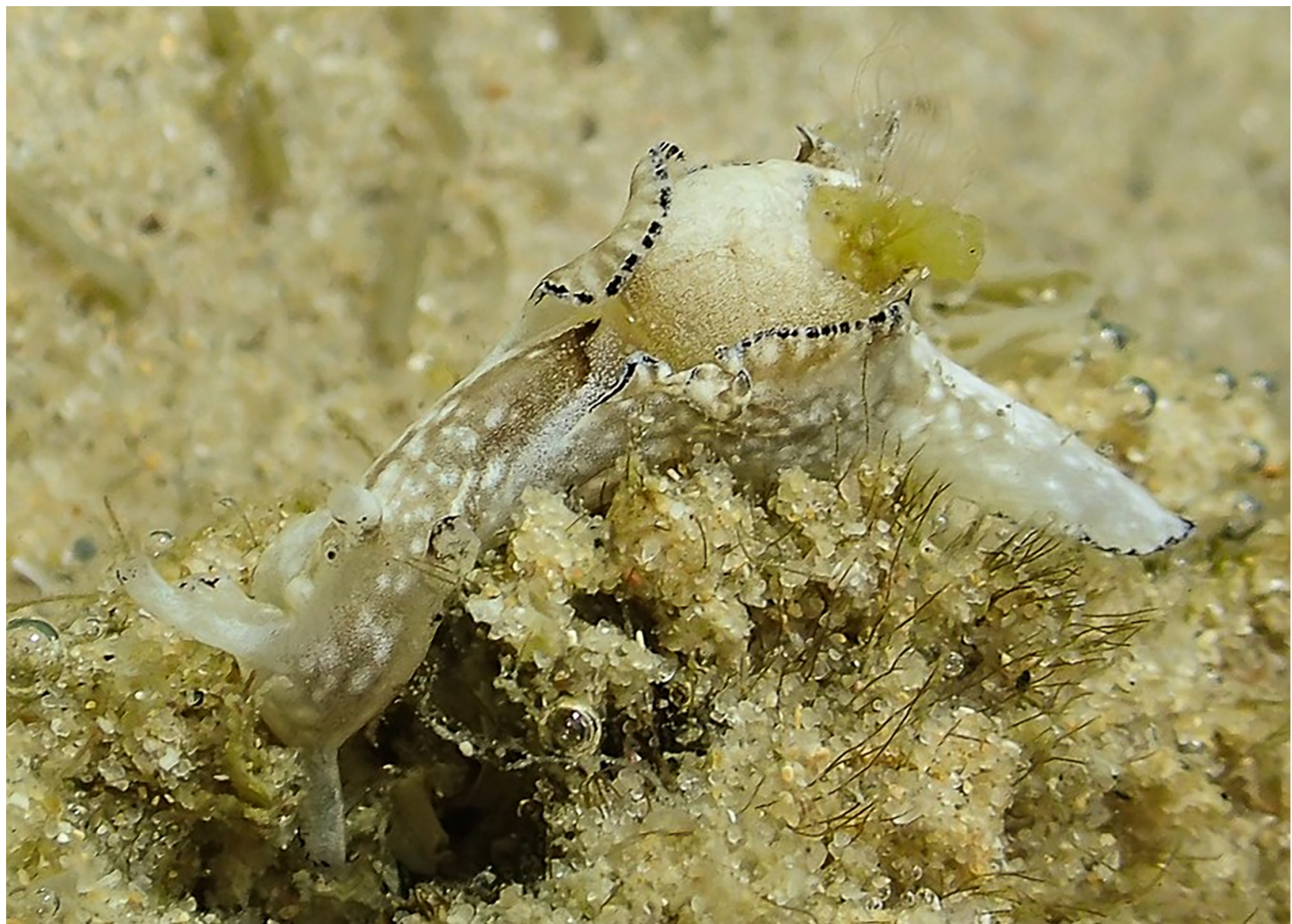

Figure 1. Photograph of living neotype of Aplysia concava, specimen AMS C.574820, Newcastle, NSW, Australia, collected 14 December 2016, by Stephen D. A. Smith. Photograph: M. Nimbs.

\section{Aplysia norfolkensis G. B. Sowerby II, 1869}

G. B. Sowerby II, 1869 , p. 216, pl. 10, fig. 42A-B; type locality "Norfolk Island, New South Wales" [but later determined to be Port Jackson (= Sydney Harbour), see text];-Pilsbry, 1895, vol. 16, p. 100.

Tethys norfolkensis.-Hedley, 1906, p. 536, pl. XXXIII, figs 33, 34;--Singleton, 1937, p. 296.

Although Sowerby II lists the type locality for A. norfolkensis as "Norfolk Island, New South Wales", later authors assert that the type specimen was collected by John Brazier (Australian Museum) who then supplied the shell to Sowerby (Burn, 2019; Hedley, 1906). According to Hedley (1906), Brazier's specimens were collected from Sydney Harbour, NSW.

Sowerby's original description, as with many 19th century sea hare descriptions, was based solely on a shell. The shell illustrated by Sowerby (Fig. 2), was described as exhibiting an "... auricle produced by the reflected dorsal margin [which] is more expanded in Aplysia concava than in this similarly shaped but differently coloured shell" (Sowerby II, 1869, p. 216). Later, however, Pilsbry (1895) suggested that $A$. norfolkensis was probably synonymous with $A$. concava. Hedley described and figured a living specimen of $A$. norfolkensis (Hedley, 1906; pl. xxxiii, figs 33, 34) and provided a description and drawings of the mantle characteristics which are consistent with those found in $A$. concava (Nimbs \& Wilson, 2021).

A single shell of $A$. norfolkensis collected by Brazier, from Bradleys Head, Port Jackson, Sydney, NSW, Australia on 25 June 1892 was examined and photographed as part of the present study (Fig. 3A, B). The morphology of this shell agrees with Sowerby's original painting of $A$. norfolkensis. Additionally, this distinctive, concave shell is consistent with that found in A. concava (Nimbs \& Wilson, 2021). Consequently, Aplysia norfolkensis G. B. Sowerby II, 1869, is herein regarded as a junior synonym of Aplysia concava G. B. Sowerby I, 1833 . 
Species 24. (Fig. $a, b$, Mus. Sowerby.)

Aplysia concava. Apl. testa parva, straminea, tereui, ventricosâ, transversa, lavigat $\hat{a}$, intìs alba ; apice parva, rotunda, validè incurva, utrinque subauriculata; margine superiori concava, brevi, ad terminum elevata ; labio externo anticè obliquè producto; margine dorsali reflexo, elevato, obliquè versùs labium externum declivi.

The concave Aplysia. Shell small, straw-coloured, thin, ventricose, transverse, smooth, white within ; apex small, rounded, strongly incurved, subauriculated on both sides, upper side concave, short, dorsal margin reflected, elevated, oblique sloped towards the outer lip.

Sowerby. Genera of Shells.

Hab. Australia.

Aplysia anguilla is more transverse, and Aplysia rosea more triangular than this species, although they nearly resemble it; the apex is auriculated, and the reflected lateral margins near it.

Species 42. (Mus. Sowerby.)

Aplysia Norfolkensis. A pl. testa cornea, fusca, arcuata, ventricosa, obliquè subovata, tenui, lavigata; apice elevato, rotundo, dorso auriculato; margine superiori declivi, excavato; labio externo convexiùsculo; margine inferiori rotundo; margine dorsali arcuato, rotundo, prope apicem tenuiter reflexo, versìs terminum inferiorem obliquè inclinato.

The Norfolk Island Aplysia. Shell horny, brown, arched, ventricose, obliquely subovate, thin, smooth; apex elevated, round, auriculated at the back; upper margin sloped, excavated; outer lip rather convex; lower margin rounded, dorsal margin arched; rounded, thinly reflected near the apex, obliquely inclined towards the lower end.

Sowerby.

Hab. Norfolk Island, New South Wales.

The auricle produced by the reflected dorsal margin is more expanded in Aplysia concava than in this similarly shaped but differently coloured shell.

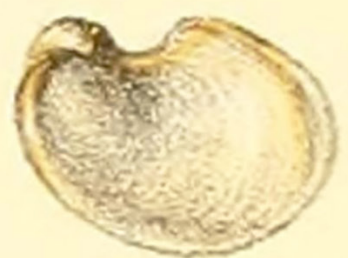

24. $\alpha$

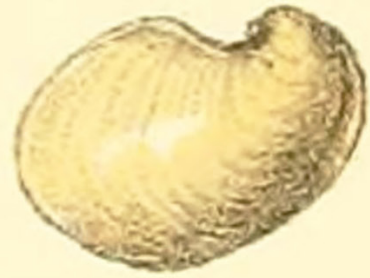

24,0 .

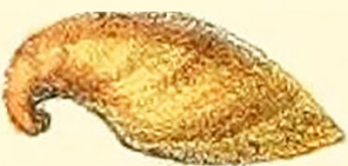

$42 . a$

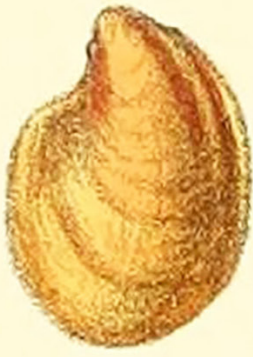

42. b.

Figure 2. Original descriptions and figure illustrations of shells for Aplysia concava G. B. Sowerby I, 1833: vol. 2, p. 243, pl. 235, figs 24a,b; and Aplysia norfolkensis G. B. Sowerby II, 1869: vol. 17, p. 216, pl. 10, figs 42a,b. Sourced from Biodiversity Heritage Library, (see Sowerby I, 1833; Sowerby II, 1869). 


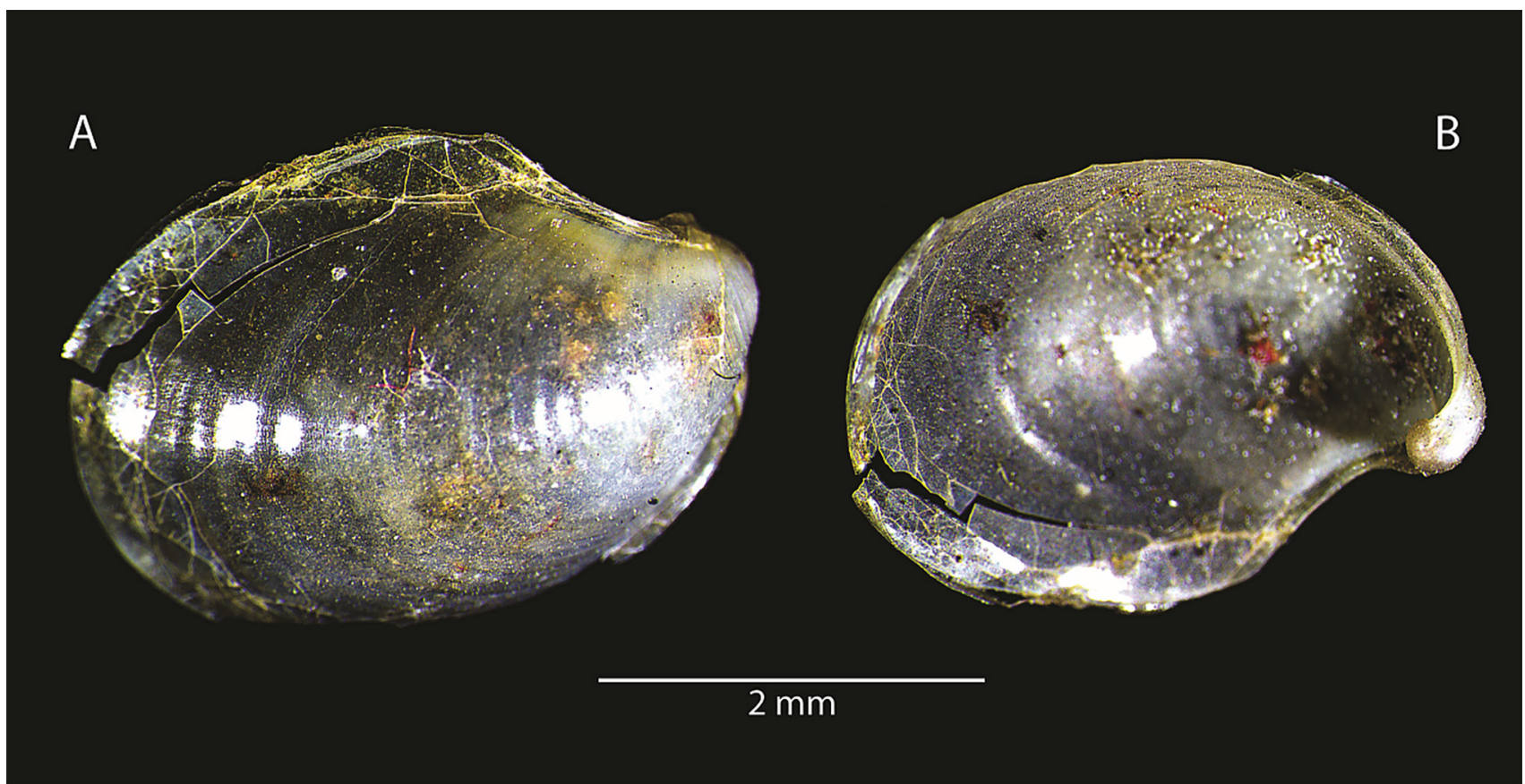

Figure 3. Light microscope image of Aplysia norfolkensis shell, (a) dorsal view, (b) ventral view, specimen AMS C.55733, collected by Brazier, J., 25 June 1892, Bradleys Head, Port Jackson, Sydney, NSW, Australia. Photograph: M. Nimbs.

ACKnOwledgements. Gratitude is extended to Mandy Reid of the Australian Museum, Sydney, Steve Smith and staff from the National Marine Science Centre, Southern Cross University and Bob Burn from Museum Victoria.

\section{References}

Burn, R. 2019. Name changes for Victorian sea slugs and bubble shells. Newsletter of the Malacological Society of AustralasiaVictorian Branch Bulletin 299: 4.

Eales, N. B. 1960. Revision of the world species of Aplysia. Bulletin of the British Museum (Natural History) Zoology 5: 370-380. https://doi.org/10.5962/bhl.part.11725

Golestani, H., F. Crocetta, V. Padula, Y. Camacho-García, J. Langeneck, D. Poursanidis, M. Pola, M. B. Yokeş, J. L. Cervera, D.-W. Jung, T. M. Gosliner, J. F. Araya, Y. Hooker, M. Schrödl, and Á. Valdés. 2019. The little Aplysia coming of age: from one species to a complex of species complexes in Aplysia parvula (Mollusca: Gastropoda: Heterobranchia). Zoological Journal of the Linnean Society 187(2): 279-330.

https://doi.org/10.1093/zoolinnean/zlz028

Hedley, C. 1906. Studies on Australian Mollusca, part ix. Proceedings of the Linnean Society of New South Wales 30: 536. https://doi.org/10.5962/bhl.part.12915

International Commission on Zoological Nomenclature. 1999. International Code of Zoological Nomenclature, fourth edition. London: International Trust for Zoological Nomenclature, xxix $+306 \mathrm{pp}$.

Nimbs, M. J., R. C. Willan, and S. D. A. Smith. 2017. Is Port Stephens, eastern Australia, a global hotspot for biodiversity of Aplysiidae (Gastropoda: Heterobranchia)? Molluscan Research 37: 45-65. https://doi.org/10.1080/13235818.2016.1207280

Nimbs, M. J., R. C. Willan, and S. D. A. Smith. 2017. An historical summary of the distribution and diet of the Australian sea hares (Gastropoda: Heterobranchia: Aplysiidae). Zoological Studies 56(35): 1-15.

https://doi.org/10.6620/ZS.2017.56-35

Nimbs, M. J., and N. G. Wilson. 2021. Saved by the shell: molecular analysis detects the cryptic sea hare, Aplysia concava G. B. Sowerby I, 1833 (Mollusca: Heterobranchia: Aplysiidae), from Oceania, with a redescription. Taxonomy 2021(1): 48-59. https://doi.org/10.3390/taxonomy10200060

Pilsbry, H. A. 1895. Manual of Conchology, Structural and Systematic, with Illustrations of the Species. Ser. 1. Vol. 16: Philinidae, Gastropteridae, Aglajidae, Aplysiidae, Oxynoeidae, Runcinidae, Umbraculidae, Pleurobranchidae, pp vii, 1-262, pls 1-74. Philadelphia: Conchological Section, Academy of Natural Sciences.

https://doi.org/10.5962/bhl.title.10543

Reid, A. L., S. T. Ahyong, S. J. Keable, E. Kupriyanova, K. Layton, and A. C. Miller. 2017. The Australian Museum Lord Howe Island Expedition 2017-marine invertebrates. Technical Reports of the Australian Museum, Online 26: 9-18. https://doi.org/10.3853/j.1835-4211.26.2017.1707

Singleton, F. A. 1937. Lady Julia Percy Island: Report of the expedition of the McCoy Society for Field Investigation and Research. No. 14, Mollusca. Proceedings of the Royal Society of Victoria 49: 396.

Sowerby I, G. B. 1833. The Genera of Recent and Fossil Shells, for the use of Students, in Conchology and Geology, vol. 2, pl. 235, fig. 3 and unpaginated text. London: Sowerby. https://doi.org/10.5962/bhl.title.86281

Sowerby II, G. B. 1869. Monograph of the genus Aplysia. In Conchologia Iconica, vol. 17, pls 1-10 and unpaginated text. London: L. Reeve \& Co.

https://doi.org/10.5962/bhl.title. 8129 